\title{
Psalm 122: Jerusalem reviviscut!
}

\author{
H. Viviers \\ Dept. Bybelkunde \\ Randse Afrikaanse Universiteit \\ JOHANNESBURG
}

\begin{abstract}
An incisive literany analysis of Psalm 122 as well as the reconstruction of the possible historical context is necessary to fully grasp the original impact and function of this psalm. Sociological models have proved to be useful for the reconstruction of the (macro-) context. Psalm 122 is a post-exilic (ca 445-350 B.C.) psalm bringing hope in a disconsolate situation with its main theme being "Jenusalem! where Yahweh is". In this regard it matches its wider literary context, the ma "alat collection. The poet portrays rebuilt Jerusalem as being 'greater' than it actually was to enhance his message. He endeavours to 'revive' contemporary Jerusalem on the model of the glorious Jerusalem gone by. In this way he could 'revive' his people's faith as well.
\end{abstract}

\section{INLEIDING}

Psalm 122 mag met die eerste oogopslag na ' $n$ redelike eenvoudige psalm lyk, maar is in werklikheid 'n baie ingewikkelde gedig. Nie alleen word die hooftema van hierdie psalm uiters gesofistikeerd (en treffend) deur die digter gekommunikeer nie, maar die moeilik bepaalbare historiese voedingsbodem daarvan is van wesensbelang vir die verstaan daarvan. Laasgenoemde vorm nie mar net die 'agtergrond' van die psalm nie, maar verskaf onontbeerlike 'grond' vir die verstaan daarvan.

Nie alle geleerdes stem saam oor die literêre (kuns-) gehalte van hierdie psalm (en ander) nie. Daarom sal daar in wat verder volg prominent op hierdie aspek (opbou, eenheid en poëtiese tegnieke) van die psalm gefokus word en sal daar gepoog word om aan te toon dat hier inderdaad 'n bedrewe digter aan die werk was.

Vervolgens sal gepoog word om Psalm 122 histories te 'plaas' aangesien 'n voor- of naeksiliese situering van Psalm 122 die interpretasie daarvan aansienlik verander. In die situering sal spesifiek gefokus word op die vraag na die 'waarom?' van Psalm 122, nadat die 'antwoord' uit die literêre profiel van die psalm bepaal is. Die nagaan van die 'waarom' van Psalm 122 is 'n spesifiek sosiologiese vraag (Gous, 1988:19; vgl. ook Brueggemann, 1979:168) in 'n poging om iets van die sosiale dinamiek van die destydse situasie in die generering van die psalm te belig. Op die vraag na die 'waarom' van Psalm 122 is natuurlik dikwels al geantwoord, dog nie bewustelik vanuit 'n sosiologiese 
aanpak nie en daarom is dié antwoord weer onbevredigend juis ten opsigte van die dinamiese rol van die samelewing by teksproduksie. In navolging van Gous word gebruik gemaak van die sosiologiese insigte van C. Geertz (1973) en W. Brueggemann (1979). Geertz (1973:87-125), beskryf die algemene rol van godsdiens in 'n samelewing, terwyl Brueggemann dit (onafhanklik van Geertz) in essensie 'illustreer' aan die hand van die twee hooftrajekte of tradisiestrome in die Ou Testament, naamlik 'n Mosaïese en in Dawidiese trajek. Brueggemann se studie oor die psigologiese en sosiologiese funksies van die Psalms (1980) word ook gebruik om Psalm 122 te klassifiseer. Relevante sosio-historiese inligting en die breër konteks van Psalm 122, naamlik die ma'alôt-bundel (Ps. 120-134), kom ook kortliks onder die loep.

\section{DIE TEKS VAN PSALM 122}

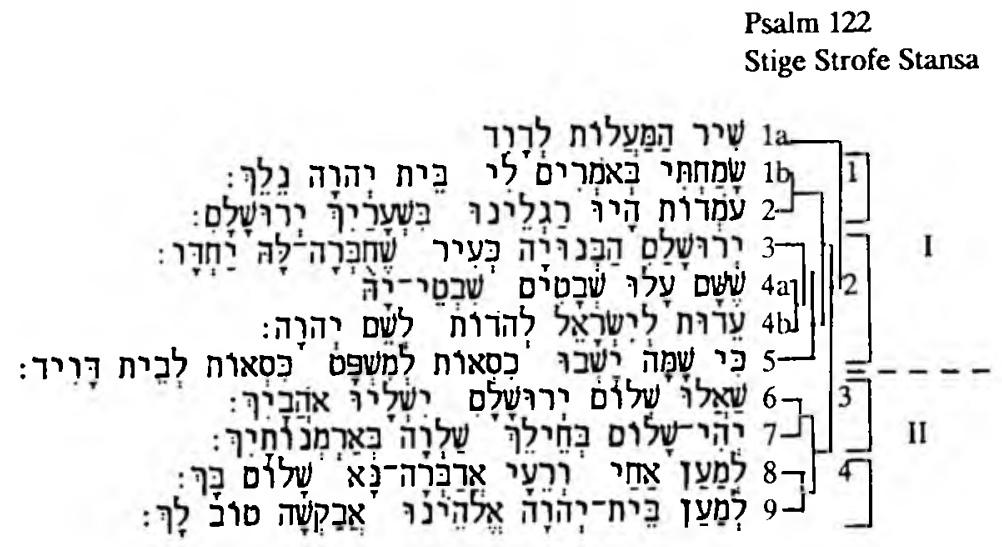

Psalm 122 bestaan uit twee stansas. Stansa I bestaan uit twee strofes van ongelyke lengte, naamlik 'n inleidingstrofe, strofe 1 (stiges $1 b-2$ ) en strofe 2 (stiges 3-5). Stansa II bestaan uit twee strofes van gelyke lengte, naamlik strofe 3 (stiges 6-7) en strofe 4 (stiges 8-9).

Strofe 1 se stiges 1 b en 2 word verbind deur die eerstepersoon meervoud in die werkwoord נִ נר wat weer opgeneem word in die suffiks van die eerstepersoon meervoud in 7 ב 7 , die voorvoegsel (1b-temporeel, 2-adverbiaal) in albei, en partisipia wat in albei stiges voorkom. Verder is daar 'n inhoudelike verbinding tussen "huis van Jahwe" (1b) en "Jerusalem" (2).

Strofe 2 se stiges word soos volg verbind: $4 \mathrm{a}$ en $4 \mathrm{~b}$ is in albei stiges verbind deur $\mathrm{rl}$ ? en

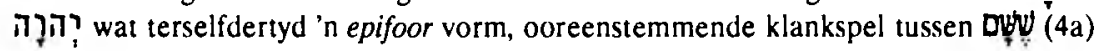


en $\mathbb{W}$ ל (4b) kom voor, en inhoudelik vloei $4 \mathrm{~b}$ voort uit $4 \mathrm{a}$. Ook word die $\boldsymbol{W}$-alliterasie van 4a in 4b gekontinueer. Die hapax legomenon

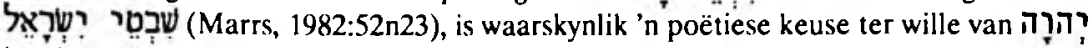
in stige $4 b$. Klankspel ( 3 ,-uitgange) met die vorige stige kon moontlik ook 'n rol in dié keuse gespeel het. Vervolgens is 3 aan $4 a-b$ verbind deur die $\underset{f}{~ p a r t i k e l ~}(3,4 a)$ wat 'n anadiplose vorm, die סֶָ (4a) wat terugverwys na "Jerusalem" en klankspel tussen die

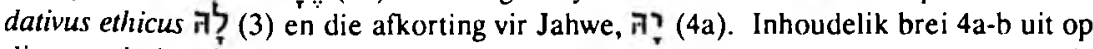
die tweede hemistige van 3. Hier word Donner (1988:84-86) se standpunt nagevolg wat Duhm (1899:270-271) en Luther se interpretasie van stige 3 steun. Luther vertaal hierdie stige soos volg: "Jerusalem ist gebaut, daß es eine Stadt sei, da man zusammenkommen soll." Hier word dus vir die 'gemeenskaps'-interpretasie gekies (vgl. ook Weiser, 1966:517-518; Lamparter, 1965:287) bo die 'argitektoniese' interpretasie asof Jerusalem stewig 'saamgevoeg' sou wees. Die onmiddellike konteks van stige 3 (3-5) asook die res van die psalm (vgl. veral stige 8) steun eerder die 'gemeenskaps'-interpretasie.

Stige $3-4 b$ is verbind aan stige 5 deur die 7 (bevestigende) partikel ${ }^{1}$, die ?

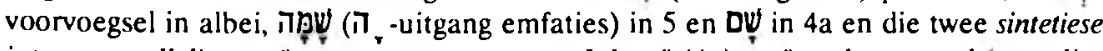
interne parallelismes, "stamme, stamme van Jahwe" (4a) en "stoele ..., stoele van die huis van Dawid" (5). Laasgenoemde word deur Seybold (1979:251) ten onregte as 'n glos beskou, waar hy kennelik hierdie herhalende interne parallelismes nie raaksien nie. Die 'gemeenskapsmotief' (3-4b: godsdienstige aksent) word hier in 5 voortgesit (regsaksent).

Strofe 2 word verder heg saamgebind deur 'n netwerk van chiasmes en klankpatrone. Daar is ' $n$ inhoudelike chiasme tussen 3 en $4 \mathrm{a}$ :

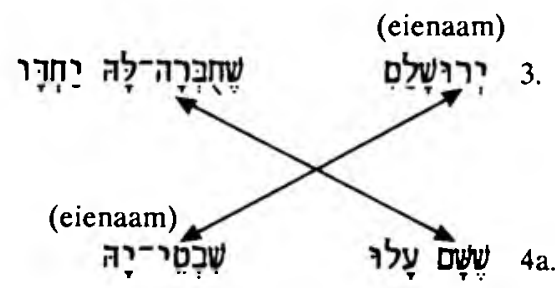

Stiges 3-5 vorm 'n inhoudelike chiasme (vgl. struktuuranalise hierbo):

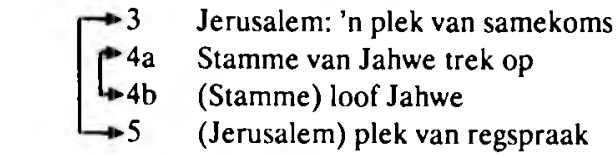

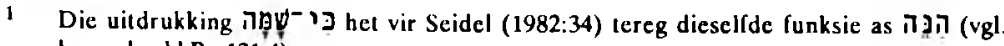
byvoorbecld Ps. 121:4). 
Psalm 122: Jerusalem reviviscut!

Verder is daar 'n 'klank-inhoud'-chiasme ${ }^{2}$ tussen 4 b en 5 :

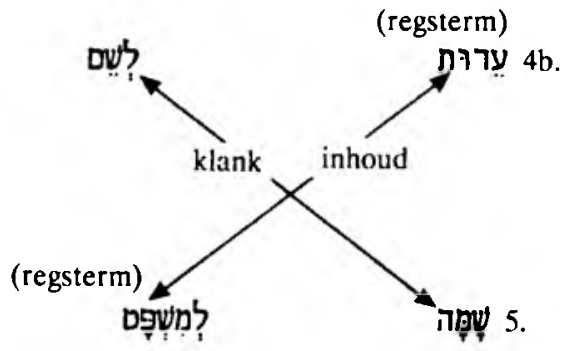

Hierdeur word ook die standpunte van Briggs en Briggs (1969:448,450) en Seybold (1979:251) gediskrediteer asof $4 b$ (of dele daarvan) 'n glos sou wees (vgl. weer ook die hegte verbinding van $4 a$ en $4 b$ hierbo).

'n Sigsag paronomasia-patroon loop regdeur strofe 2:

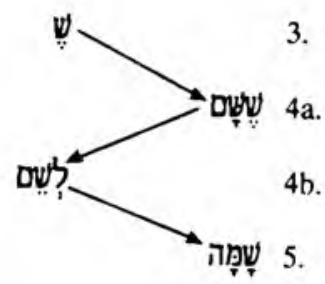

Oor die verdere funksies van hierdie patrone word hieronder uitgebrei.

Strofes 1 en 2 word verbind deur "Jerusalem" in 2 en 3 wat 'n anadiplose vorm, die "huis van Jahwe" (1b) en die "huis van Dawid" (5) wat 'n inclusio vorm binne stansa I, "Jahwe" in 1b, 4a, en $4 b$ en die inhoudelike uitbreiding van strofe 1 binne strofe 2.

Strofe 3 se stiges 6 en 7 word verbind deur die imperatief (6) en jussief (7) waarmee albei begin en in wese dieselfde funksie het, 2 W in albei, die stam in albei (eers as ww., dan as subst.) en die suffikse van die tweedepersoon vroulik enkelvoud in albei. Die inhoudelike sinonieme paralleliteit van albei stiges word ook bevestig deur die

$2 \quad \mathrm{ggl}$. Viviers (1992) vir 'n volledige bespreking van hierdie stylfiguur. 
posisies van die woorde של שלה (in albei stiges die tweede woord) en stiges die tweedelaaste woord). Hierdeur vertoon die twee stiges terselfdertyd trekke van 'n anafoor asook van 'n epifoor om sodoende symploke te vorm. Die opvallende $\boldsymbol{W}$ alliterasie van 6 word voortgesit in 7 en die paronomasia tussen

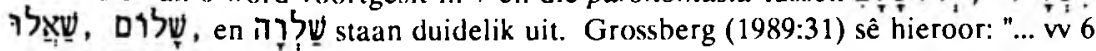
and 7 carry the punning to an extreme". Dit word alles baie duidelik gedoen om die

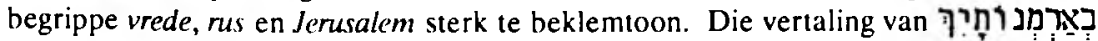
(7) as "jou torings" (bo-op stadsmuur) is te verkies bo die vertaling van "paleise", in die lig van die parallelle "skanse" van die eerste hemistige (vgl. ook Burden, 1991:32). Watson (1980:327) se tipering van stige 7 as gender-matched synonymous parallelism versterk genoemde keuse.

Strofe 4 se stiges 8 en 9 is sintakties feitlik identies, hoewel semanties effens verskillend (Marrs, 1982:195). In alhei stiges word Jerusalem "geseën", eers ter wille van "die Juden als Blutsverwandte und Mitbürger" (Duhm, 1899:271) en tweedens ter wille van die tempel van Jahwe. In teenstelling met die anaforiese en epiforiese 'trekke' van die vorige strofe, kom albei hierdie stylfigure hier eksplisiet na vore (לַַ? aan die begin en $\underset{\text { en }}{\text { en }}$ a

Strofes 3 en 4 word verbind deur die uitgange van die tweedepersoon vroulik enkelvoud (7-) wat 'n opvallende eindrympatroon regdeur stansa II vorm, die J voorsetsel $(7,8)$ en 1980:404). Verder is daar in albei strofes die stylfigure anafoor, epifoor, symploke en parallelisme (Marrs, 1982:194-196). Die 'metrum' in stansa II volg ook deurgaans 'n $3+2$ patroon.

Stansas I en II word verbind deur die eienaam "Jerusalem" $(2,3,6)$ en die tweedepersoon enkelvouduitgange (= Jerusalem) (2,5,6,7,8), die היה stam (2,7), "Jahwe" (ook "huis van Jahwe", "naam van Jahwe") $(1 b, 4 a, 4 b, 9)$ en "ons" $(2,9)$. 'n Sterk verbinding

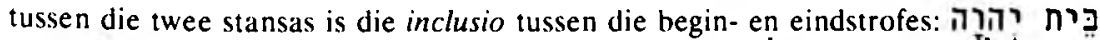

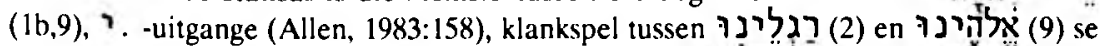

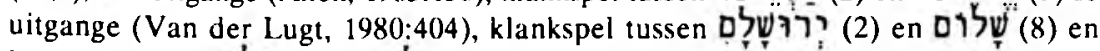
klankspel tussen נָלרך (1b) en (9). Dat stige 9 'n glos sou wees (Seybold, 1979:251), verdien in die lig hiervan nouliks kommentaar (vgl. weer ook die verbinding tussen 8 en 9). Die twee stansas word verder heg saamgebind deur die paronomasia tussen

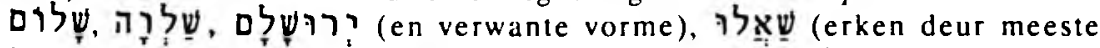

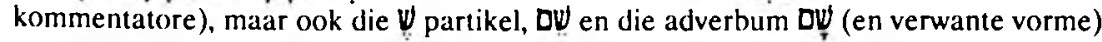
regdeur die psalm.

Saam met die inclusio sien Alden (1978:206) tereg ook korresponderende elemente tussenin, sodat Psalm 122 'n chiastiese patroon in die geheel vertoon: 
1 A Joy at going to the house of the LORD

2-3 B Description of Jerusalem

$4 \quad$ C There the tribes go up

$5 \quad C$ There are the thrones

6-7 B Peace of Jerusalem

8-9 A Seeking the good of the house of the LORD.

'n Balans kom verder tussen die twee stansas van die psalm na vore deur die chiasmes (strofe 2) wat gebalanseer word deur die parallelismes van stansa II. Die klankelemente Wֶ, שֶׁ (strofe 2), word weer mooi gebalanseer deur die klankele-

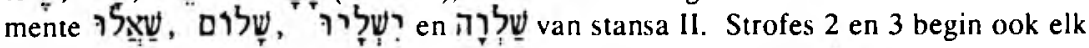
met ooreenstemmende assonansie. Strofe 2 se stige 3 se a- en u-assonansie onderstreep Jerusalem subtiel as 'bymekaarkomplek'. Strofe 3 se stige 6 se a- en û-assonansie onderstreep weer subtiel die erns van die versoek om vrede vir Jerusalem. Die chiasmes. anadiplose en klankpatrone van strofe 2 laat die klem sterk op Jerusalem val as die godsdienstige, politieke en regsetel (vgl. ook Marrs, 1982:44,46,47). Hierdie klem op Jerusalem word geintensiveer deur die parallelismes en klankspel van veral strofe 3: "Jerusalem, jy verdien vrede en rus!" Die direkte aanspreekvorm ( $2^{\mathrm{e}}$ pers. vr. ekv. deurgaans in stansa II), impcratief $(6)$, kohortatief $(8,9)$ en die eindrym $(6,7,8,9)$ dra hiertoe by. Die personifikasie van Jerusalem wat in stige 2 met 'n vokatief aanvang, word veral hier in stansa II sterk uitgebou.

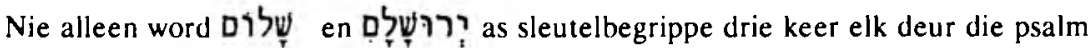

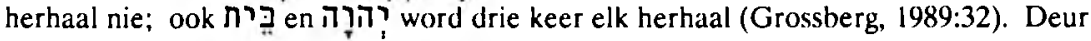
hierdie herhaling van sleutelbegrippe word Jerusalem gekwalifiseer. Dit gaan nie oor Jerusalem as sodanig nie, maar oor die "huis van Jahwe" daarin (Gemser, 1968:175). Hierdie klem op die "huis van Jahwe" word baie effektief verkry deur dit in die inclusio te laat voorkom, sodat dit die psalm tematies omraam - "Jerusalem is waar Jahwe is!"

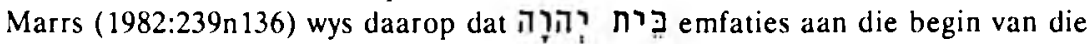
tweede hemistige van stige $1 \mathrm{~b}$ voorkom. In stige 9 is "huis van Jahwe, ons God" weer eens emfaties voorop geplaas. Die hendiadis (Watson, 1986:324-328) "huis van die Here, ons God" dra tot hierdie klem by! Saam met die hendiadis in stige 8 "my broers en my vriende" (Dahood, 1970:207), word Psalm 122 baie effektief ook met closure opgesom en afgesluit.

Die digter van Psalm 122 is voorwaar 'n vakman. Elke bousteen, van die eenvoudigste tot die mees ingewikkelde patroon, dra daartoe by om van die gedig in sy geheel ' $n$ treffende kunswerk te maak. Die klank-'infrastruktuur' van Psalm 122 veral, is baie opvallend.

Naas die literêre redes vir hierdie lofsang op Jerusalem (Gattung) is daar ook sosio- 
historiese redes waarom Jerusalem so 'opgehemel' word. Die sosio-historiese konteks van Psalm 122 sal vervolgens nagegaan word.

\section{DIE KONTEKS VAN PSALM 122}

\subsection{Datering}

Hoewel sommige eksegete Psalm 122 na-eksilies wil dateer op grond van Arameïserende taalverskynsels (bv. die Vy-partikel e.a. vreemde vorme) is dit in isolasie beskou, nie genoegsame getuienis vir 'n láát datering nie (vgl. Allen, 1983:158). 'n Ander weg wat ingeslaan word, hou verband met die vertaling van stige 2 . 'n Teenwoordige-tydvertaling lei gewoonlik tot 'n voor-eksiliese datering waarin die glorie van die tempel besing word (bv. Allen, 1983:157). 'n Verlede-tyd-vertaling lei gewoonlik tot 'n naeksiliese datering waarin daar met heimwee teruggekyk/terugverlang word na die glorieryke eerste tempel (bv. Donner, 1988:81-84). Tog vertaal Seybold (1978:88) stige 2 in die teenwoordige tyd, maar hou vas aan 'n na-eksiliese datering. Stige 2 , in die teenwoordige of in die verlede tyd vertaal, is nie deurslaggewend vir datering nie en beide moontlikhede kan goedskiks op enige twee van die tempelsituasies ( $1^{\mathrm{c}}$ of $2^{\mathrm{c}}$ ) betrekking hê. Die begrip בנה (hou) in stige 3 bring ons nader aan 'n antwoord. Daar is redelike eenstemmigheid dat hierdie begrip herbou beteken (vgl. Donner, 1988:85; Seybold, 1978:39-40,54; Kittel, 1922:392). Die herboude tweede tempel (en stad) word dus veronderstel, dit wil sê 'n situasie ná 515 v.C. doen sigself voor. 'n Nadere datering is moontlik omdat daar in stige 7 van die (herboude) mure van Jerusalem sprake is, 'n taak wat deur Nehemia na \pm 445 v.C. voltrek is (Anderson, 1988:521-533). Die datum 445 v.C. sou dus kon geld as die teminus a quo en 350 v.C. as die terminus ad quem (vgl. Burger, 1987:17-19) vir Psalm 122. Psalm 122 vorm ook onlosmaaklik deel van die $m a{ }^{\prime}$ alot $t$-bundel (vgl. Viviers, 1990) wat na-eksilies gedateer word tussen 515 v.C. en 400 v.C. (Seidel, 1982:38; Seybold, 1978:75; e.a.). Eersgenoemde tydspan (vir Ps. 122) sou ook as 'n nader datering van die hele bundel kon geld. Donner (1988:86-89) se verklaring van Psalm 122 as die terugskou op en die nostalgiese in herinnering roep van historiese besienswaardighede (soos bv. stige 5 se "stoele van die gereg" en "stoele van die huis van Dawid"), met die tweede tempel voor oë, is oortuigend (vgl. ook Seybold, 1978:23-24; Kittel, 1922:392).

\subsection{Die sin en doel van godsdiens in 'n samelewing}

Alvorens daar gevra word na die funksie van Psalm 122, moet daar eers gevra word na die sin en doel van godsdiens in 'n samelewing in die algemeen. Die kultuurantropoloog C. Geertz (1973) verskaf hierop 'n goeie antwoord. Gous $(1988: 29,39)$ 
toon tereg aan hoe Geertz teenoor die deterministiese (simplistiese) verklarings van godsdiens asof dit maar net sosiologiese projeksies van die samelewing is om laasgenoemde goed en glad te laat funksioneer (bv. Durkheim, Weber, Freud, Feuerbach, Marx, ens.), aan godsdiens ook 'n intellektuele funksie toeken. Dit weerspieël nie maar net samelewingspatrone nie, maar help dit ook vorm (Geertz, 1973:119,124). Godsdiens as ingewikkelde fenomeen kan hierdeur veel meer tot sy reg kom. Volgens Geertz is godsdiens 'n kultuursisteem, 'n sisteem van simbole wat die gevolg is van die mens se inherente behoefte aan sin (Gous, 1988:45). Godsdiens verskaf aan mense'n wêreldbeeld, 'n prentjie van hoe die werklikheid daar uitsien en georden is ('n model van die werklikheid). 'n Wêreldbeeld verklaar vir die mens onder andere sy plek in die wêreld, God s'n, die rol van die natuur, die posisie van die gemeenskap, ensomeer. Wêreldbeeld behels die mees algemene idees van orde. Dit wat die mens intellektueel uit die wêreldbeeld wys word, bepaal eksistensieel hoe hy behoort te lewe ('n model vir die werklikheid). Geertz (1973:128) illustreer die wedersydse beinvloeding van wêreldbeeld en etos treffend met as voorbeeld, 'n primitiewe stam, die Oglala:

The Oglala believe the circle to be sacred because the great spirit caused everything in nature to be round except stone. Stone is the implement of destruction. The sun and the sky, the earth and the moon are round like a shield, though the sky is deep like a bowl. Everything that breathes is round like the stem of a plant. Since the great spirit has caused everything to be round mankind should look upon the circle as sacred, for it is the symbol of all things in nature except stone. It is also the symbol of the circle that makes the edge of the world and therefore of the four winds that travel there. Consequently it is also the symbol of the year. The day, the night, and the moon go in a circle above the sky. Therefore the circle is a symbol of those divisions of time and hence the symbol of all time.

For these reasons the Oglala make their tipis circular, thcir camp-circle circular, and sit in a circle at all ceremonies. The circle is also the symbol of the tipi and of shelter. If one makes a circle for an ornament and it is not divided in any way, it should be understood as the symbol of the world and of time.

Die wêreldbeeld van die Oglala is 'sirkel-agtig' en hulle dink en doen gevolglik in 'sirkels'. Godsdienstige rituele (Geertz, 1973:112-118) het ten doel om die wêreldbeeld en etos in stand te hou, lewend te hou.

\subsection{Die Mosaïese en die Dawidiese trajek}

W. Brueggemann (1979) illustreer in wese die insigte van Geertz deur twee trajekte of tradisiestrome in die Ou Testament te identifiseer, elk met sy eie wêreldbeeld en etos. Die Mosaïese trajek het ontstaan in die premonargale tydvak en die Dawidiese in die monargale tydvak en beide loop dan regdeur tot en met die afsluiting van die $\mathrm{Ou}$ Testament. Al die onderskeie tradisies in die Ou Testament hoort wesenlik in een van hierdie twee trajekte tuis. In die Mosaïese trajek (wortels in Noordryk) is God 'n God 
van vryheid en geregtigheid; die samelewing bestaan uit randfigure vir wie desentralisasie van mag en sosiale gelykheid belangrik is. Vanuit so 'n werklikheidsiening kan 'n mens bevrydend (revolusionêr) optree en die maghebbers en status quo kritiseer. In die Dawidiese trajek (wortels in Suidryk) is God 'n God van orde en heiligheid, die maghebber en elite in die samelewing is belangrik en hiermee saam sentralisasie van mag en 'n hiërargiese samelewing. Binne so 'n werklikheidsiening hehoort mense konsoliderend (orde-bewarend) op te tree, die maghebbers en elite se optrede te legitimeer, en oor die algemeen die status quo te ondersteun. Tereg en oortuigend wys Gous (1988:61) dat Brueggemann slegs op simptomatiese verskille konsentreer en dat hy eensydig met 'n konflikmodel (onderdrukte-onderdrukker) werk met sy stof. Met behulp van Geertz toon hy aan (1988:64) dat beide hierdie trajekte eenders funksioneer omdat albei trajekte sienings van orde (nie slegs die Dawidiese trajek nie) ten grondslag het. Sy regstelling (1988:65-60) op Brueggemann is dan dat die Mosaiese trajek op 'n mensgemaakte orde fokus waarin die mens aktief kan deelneem om 'n goeie orde teweeg te bring. Die Dawidiese trajek fokus weer op die Godgegewe orde en die mens se taak is om sinvol by hierdie orde in te skakel.

In watter trajek hoort Psalm 122 tuis? Psalm 122 pas ongetwyfeld in die Dawidiese trajek. Hierdie psalm weerspieël Sionsteologie (Seybold, 1979:268; Burger, 1987:34-36). establishment-teologie (Le Roux, 1987:104-106, 157-159) of status quo-teologie op sy duidelikste. Jahwe kies Jerusalem (Sion) as sy aardse woonplek om dáár in die tempel teenwoordig te wees (vgl. dit ook in Ps. 132, deel van die ma alôt-bundel); Hy is die inisieerder hiervan, dit is sy wilsbesluit, sy orde. Die belangrikste betekenis van Jerusalem lê in sy godsdienstige betekenis - "Jerusalem is waar Jahwe is!" (hooftema). So word Psalm 122 tematies omraam. Jerusalem is die Godstad by uitnemendheid. Jahwe het dit ook gewil dat hierdie stad die sentrale regsetel sal wees (stige 5) en die politieke setel met die Dawidiese dinastie (stige 5) wat regeer. Alles het sy plek - tempel, regspraak. koningstroon. Ook dit is sy Godgegewe orde. Verder is hierdie stad indrukwekkend gebou (ook indrukwekkend herbou? vgl. later), 'n besige bymekaarkomplek van die volk (stige 3) (moontlik ook vir handeldryf), 'n veilige toevlugsoord (poorte [stige 2], mure en uitkyktorings [stige 7]) en 'n plek van vredevolle harmoniese samesyn tussen bloed-en volksgenote (stige 8). Hierdie stad simboliseer ${ }^{3}$ alles wat goed is wat God vir sy volk daargestel het; daarom dat hierdie stad so gepersonifieer en vereer word. Van die mens word verwag om die stad (met blydskap [stige 1b]) te besoek en in te skakel en te geniet wat God deur hierdie stad aan hom bied. Die pelgrimstog ${ }^{4}$ word die ritueel (vgl. Geertz hierbo) waardeur die Dawidiese wêreldbeeld en etos lewend gehou word.

3 Gectz (1973:127) benadruk juis dat betekenis in 'n simbool, byvoorbecld 'n kruis, of in hierdie geval Jerusalem, vasgevang word.

$4 \quad$ Ps. 122 is die enigste ma alôt-psalm waar daar spesifick van 'n pelgrimslog sprake is. Dic bundel is waarskynlik corspronklik nic as 'n pelgrimshandleiding bedoel nic maar cerder as

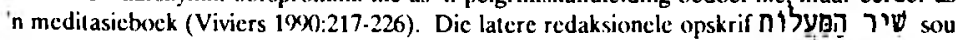
moontlik op so 'n (latere) gebruik van die bundel kon dui. Of die digler hier 'n werklike 
Dit is merkwaardig dat Psalm 122 ook in sy poëtiese struktuur en opbou indirek (onbewustelik?) iets van die orde van die Dawidiese wêreldbeeid weerspieël. Hier geld veral die stylfigure inclusio, die deurlopende chiasmes en chiastiese geheelopbou, parallelismes, die klank-'infrastruktuur' wat in beide stansas die gedig 'balanseer' en subtiel die hooftema van die psalm onderstreep, symploke (stansa II) en beide stansas van die gedig wat uit vyf stiges elk bestaan.

\subsection{Die funksie van Psalm 122 in die moontlike tydspan 445 v.C. -350 v.C.}

Met watter doel is Psalm 122 egter geskryt, watter funksie moes dit vervul in die moontlike tydspan 445 v.C.-350 v.C.? Donner (1988:86-89) se standpunt dat Psalm 122 'n nostalgiese 'terugskouing' is vanuit die huidige na die eertydse glorieryke Jerusalem as ' $n$ besondere besienswaardige plek en sentrum van die Joodse lewe, verklaar Psalm 122 se sosiale funksie slegs ten dele. Die byna oordrewe, passievolle beskrywing van Jerusalem vra na iets méér; die digter wou iets méér bereik as maar net 'n herinnering aan 'die goeie ou dae'! Die onmiddellike konteks van Psalm 122, naamlik die ma' alôtbundel (Ps. 120-134) wat voortdurend "vertroue in Jahwe" wil inskerp, sodat dit inderdaad as 'n "vertrouensboek" getipeer kan word (Viviers, 1990:220-221) ondersteun ook die aanname dat Psalm 122 meer is as 'n herinnering aan goeie maar vervloë tye. Die bundel se strewe om vertroue in Jahwe in te skerp, roep onmiddellik 'n situasie op waarin vertroue en hoop min was, 'n situasie waarin moedeloosheid. troosteloosheid en pessimisme sterk gefigureer het. Mense se geloof in Jahwe moes versterk en lewend gehou word. Die bundel weerspieêl iets van die troebel naeksiliese tyd, maar bly tog gelowig optimisties in Jahwe geanker. Le Roux (1987:151) beskryf hierdie era as 'n teleurstellende tyd: "Van die groot toekomsdroom (Eseg., Deut.-Jes., Hag., Sag. 1-8; my imvoeging - HV) het niks gekom nie, want ná die voltooing van die tempel het die lewe op sy ou, harde manier voortgegaan." Onderlinge struwelinge wat tydens die bou van die tempel voorgekom het, het warskynlik bly voortleef. Dieselfde geld ook vir spanninge met die Samaritane en die Persiese regering. Van 'n verenigde Israel was daar nie sprake nie. Jerusalem het nie die sentrum van die wêreld geword nie, maar was slegs die hoofstad van 'n minderwaardige Persiese provinsie. Die tweede tempel was in werklikheid 'n klein, niksbeduidende struktuurtjie (vgl. veral Esra 3:12-13; Hag. 2:1-9; Sag. 4:10). Hieroor laat Carrol (1991) hom soos volg uit: "... whatever constituted the second temple was a concern of a small elite and irrelevant to the wider community". Binne hierdie sosiale konteks is

pelgrimstog beskryf en of dit bloot 'n literêre skepping (n.j. die waarskynlikste) is, verander nie werklik aan die sosialc situcring van die psalm nic, aangesien die litcrère produk (gedig) iets van die sosiale werklikheid weerspiec̈l. 
dit dus verstaanbaar dat die digter van Psalm 122 Jerusalem so hoog aanslaan, Jerusalem 'groter' teken en voorstel as wat dit in werklikheid was. Gepas is Brueggemann (1980:20) se opmerking oor 'psalmtaal' in die algemeen: "The use and function of this language is not descriptive but evocative. Its knowing use can receive new worlds for the community, given by God."

Psalm 122 se lofsang op Jerusalem was dus 'n manier van moed inpraat, van geloof behou, van hoop en vertroue versterk, van nuwe horisonne oproep! Mense moes steeds vashou aan die huidige simbool wat eens dié simbool van Jahwe se teenwoordigheid en sorg was en die sentrum van die Joodse lewe - daarom gaan dit in Psalm 122 oor Jerusalem reviviscut, 'n herbevestiging nou van die nasionale God-met-onsteologie (Le Roux, 1987:157), gesetel in en gefokus op Jerusalem soos dit eens was. Die digter van Psalm 122 bly ' $n$ realis, hy kies bewustelik vir heil 'hier en nou' (Dawidiese trajek) ten spyte van die moedelose situasie en nie die latere (of gelyktydige) idealisties-visionère standpunt (Mosaiese trajek) wat die heil buite en bowe die geskiedenis begin soek het nie (bv. Mal., Trito-Jes., Sag. 9-14). ${ }^{5}$

\subsection{Psigologiese en sosiologiese reoriēntasie}

Beoordeel in die lig van Brueggemann (1980) se klassifisering van die Psalms na aanleiding van hulle psigologiese en sosiologiese funksies, is Psalm 122 'n psalm van reoriëntasie. Brueggemann sluit by Ricoeur aan wat menslike ervaring (lewe) omskryf as 'n beweging van oriëntasie na disoriëntasie en van laasgenoemde weer na 'n staat van reoriëntasie. 6 Die gebruik van die psalmbundel vandag en destyds om hierdie fluktuasie te bevredig korreleer, hoewel "kontekste en instellings" van die eietydse en destydse situasies mag verskil (Brueggeman, 1980:5). Psalms van oriëntasie het te make met die sinvolle inskakeling in die Godgegewe orde, byvoorbeeld skeppings- en wysheidspsalms (ook seënpsalms). Psalms van disoriëntasie verwoord weer die situasie/toestand van ontwrigting (dislocation), byvoorbeeld kiaagpsalms, terwyl psalms van reoriëntasie weer die verrassende herstelde ekwilibrium van die lewe vier, byvoorbeeld lof- en dankliedere. As Psalm 122 voor-eksilies geplaas sou word, dan was dit gewoon 'n psalm van oriëntasie (vgl. Allen, 1983:159), 'n saluut en wens aan 'n geliefde Jerusalem om te leef en te bly voortleef (Jerusalem vivit). Die feit dat dit egter 'n na-eksiliese psalm is, gee daaraan ' $n$ heel ander funksie, ' $n$ fokus op Jerusalem om soos vanouds glorieryk te herleef (Jerusalem reviviscut) ter bemoediging van die moedelose gemeente.

5 Of die skrywer(s) van Ps. 122 en die ma'alôt-bundel volgens Seidel (1982:37-38) in Levitiese kringe gesoek moct word, lyk twyfelagtig.

6 Vgl. ook Burden (1986:38) wat aantoon dat Ou-Testamentiese poêsie tussen blydskap en droefheid wissel. 


\section{SLOT}

Uit die opbou, eenheid en poëtiese tegnieke wat in Psalm 122 sigbaar is, is dit duidelik dat ons hier met 'n gesofistikeerde gedig te make het. Die digter van hierdie psalm is 'n vakman wat sy hooftema, Jerusalem is waar Jahwe is, effektief en geslaagd kommunikeer. Maar selfs ná 'n literêre detail-analise van die teks om dit alles vas te stel bly die funksie van die gedig onduidelik. Die funksie van Psalm 122 kon ten volle eers bepaal word nadat die gedig in die regte historiese konteks geplaas is.

Verskillende dateringe van Psalm 122 het duidelik uitgewys hoe die betekenis of bedoeling van die teks kan verander. Hierdie gegewe bevestig dat die historiese konteks nie maar net die breë agtergrond verskaf waarteen die Psalm geplaas kan word nie, maar inderdaad medebepalend is vir die korrekte verstaan van die teks. Sosiologiese modelle soos dié van byvoorbeeld Geertz en Brueggemann is van groot waarde om die dinamiek van die historiese konteks te bepaal in die generering van 'n teks soos Psalm 122. Die fokus op die sosiale dinamiek, wat aanleiding gee tot die skep van 'n literêre produk, werp onteenseglik lig op die oorspronklike funksie daarvan, verhelder die 'vraag' of 'probleem' waarvan die 'antwoord' in die teks voorhande sigbaar is. Die sosiologiese fokus op Psalm 122 kon die beter verstaan daarvan veel verder voer as byvoorbeeld Donner se historiese ondersoek van Psalm 122. Maar om ooroptimisties te wees oor sosiologiese modelle asof dit in staat sou wees om eensklaps die antieke wèreld presies te kan ontsluit, is 'n dwaling. Hierdie modelle veronderstel juis 'n arsenaal van samelewingsgegewens en nie slegs kennis oor die groot instellings soos politiek en kultus (Deist, 1987:25,43) wat ons nie het nie. Daarom moes Psalm 122 met sosio-historiese data 'reliëf gegee word (ook as deel van die $m a$ 'alôt-bundel), data wat baie min en brokstukagtig is vir die na-eksiliese tydperk onder bespreking. Maar al is die sosiale konteks van Psalm 122 nog vaag en algemeen, verklaar sosiologiese ondersoeke die dinamiese inspeel van die samelewing op 'n teks veel helderder as tradisionele historiese ondersoeke.

Meir Weiss (1976:412) is korrek as hy beweer dat onkunde oor agtergrondsfaktore nie die verstaan van 'n psalm betekenisloos maak nie. Maar as die dialektiek tussen teks en konteks glashelder uitstaan, is 'n dienooreenkomstige verstaan van so 'n teks die eindresultaat.

\section{BIBLIOGRAFTE}

ALDEN, R.L. 1978. Chiastic Psalms (III): A Study in the Mechanics of Semitic Poetry in Psalms 101150. Joumal of the Evangelical Theological Society, 21:199-210.

ALLEN, L.C. 1983. Psaims 101-150. Waco : Word Books. (Word Biblical Commentary 21.)

ANDERSON, B.W. 1988. The Living World of the Old Testament. 4th edition. Essex : Longman. 
BRIGGS, C.A. \& BRIGGS, E.G. 1969. A Critical and Excgetical Commentary on the Book of Psalms, vol 2. Edinburgh : T\&T Clark. (International Critical Commentary 15.)

BRUEGGEMANN, W. 1979. Trajectories in Old Testament Literature and the Sociology of Ancient Isracl. Jounal of Biblical Litcrature, 98(2):161-185.

BRUEGGEMANN, W. 1980. Psalms and the Life of Faith: A Suggested Typology of Function. Joumal for the Study of the Old Testament, 17:3-32.

BURDEN, J.J. 1986. Poētiese tekste. (In Deist, F.E. \& Vorster, W.S., reds. Woorde wat ver kom. Kaapstad : Tafelberg. p. 37-68.) (Literatuur van die Ou Testament 1.)

BURDEN J.J. 1991. Psalms 120-150. Kaapstad : NG Kerk-Uitgewers (Skrifuitleg vir Bybelstudent en Gemeente-recks.)

BURGER, J.A. 1987. Dic Psalms. (In Burden, J.J. \& Prinsloo, W.S., reds. Tweegesprek mel God. Kaapstad: Tafelberg. p. 9-40.) (Litcraluur van dic Ou Testamenı 3.)

CARROL, R.P. 1991. So What Do We Know about the Temple? The Temple in the Prophets. Paper delivered at the Congress of the Society of Biblical Literature. Rome.

DAHOOD, M. 1970. Psalms III, 101-150): An Introduction, Translation and Notes with an Appendix, the Grammar of the Psalter. New York: Doubleday. (Anchor Bible 17A.)

DEIST, F.E. 1987. Strominge in die geskiedenis van geskiedskrywing, en, Om 'n geskiedenis van Isracl te skryf. (In Deist, F.E. \& Le Roux J.H. Rewolusie en reinterprelasic: Hoofstukke uit die geskiedenis van Isracl. Kaapstad : Tafelberg. p. 1-30, 31-45.) (Literatuur van die Ou Testament 4.)

DONNER, H. 1988. Psalm 122. (In Claassen, W., ed. Text and Context: Old Testament and Semitic Studies for F.C. Fensham. Sheffield : JSOT Press. p. 81-91.) (Journal for the Study of the Old Testament Supplement Series 48.)

DUHM, B. 1899. Die Psalmen. Tübingen: JCB Mohr (Paul Siebeck). (Kurzer Hand-Commentar 14.)

GEERTZ, C. 1973. The Interpretation of Cultures. New York : Basic Books.

GEMSER, B. 1\%88. De Psalmen: Teksi en Uilleg. Nijkerk : Callenbach.

GOUS, 1.G.P. 1988. Dic herkoms van Klaagliedere. Preloria : Unisa. (D. Th. proefskrif.)

GROSSBERG, D. 1989. Centripetal and Centrifugal Structures in Biblical Poctry. Atlanta : Scholars Press. (Society of Biblical Literature Monograph Series 39.)

KITTEL, R. 1922. Die Psalmen. 3/4 Auflage. Leiprig : ADV. (Kommentar zum Alten Testament 13.)

LAMPARTER, H. 1965. Das Buch der Psalmen II: Psalm 73-150. 2. Auflage. Stuttgart : Calwer Verlag (Botschaft des Alten Testaments 15.)

LE ROUX, J.H. 1987. Teologic in 'n krisis. (In Deist, F.E. \& Le Roux, J.H Rewolusic en rcinterpretasic: Hoofstukke uit dic geskiedenis van Isracl. Kaapstad : Tafelberg. p. 101-159.) (Literatuur van dic Ou Testament 4.)

MARRS, R.R. 1982. The šyn'-Hmc/wl (Psalms 120-134): A Philological and Stylistic Analysis. Baltimore : The Johns Hopkins University (Ph D thesis.)

SEIDEL, H. 1982. Wallfahrtslieder. (In Das lebendige Wort: Festgabe fur Gottfried Voigt. Berlin : Evangelische Verlagsanstalt. p. 26-40.)

SEYBOLD, K. 1978. Dic Wallfahrispsalmen: Studien zur Entstchungsgeschichte von Psalm 120-134. Neukirchen-Vluyn : Neukirchener Verlag.

SEYBOLD, K. 1979. Dic Redaktion der Wallfahrtspsalmen. Zeitschrift für die alttesiamentliche Wissenschaft, 91(2):247-268.

VAN DER LUGT, P. 1980. Strofische structuren in de Bijbels-Hebreeuwse poézie. Kampen : J.H. Kok. (Dissertationes Neerlandicac Scries Theologica.)

VIVIERS, H. 1990. 'n Teksimmanente ondersock na die samchang van dic ma' alôt-psalms (Pss. 120134). Pretoria : Universitcit van Pretoria. (DD proefskrif.)

VIVIERS, H. 1992. Klank-inhoud-chiasme in dic ma alôt-psalms (Ps. 120-134). Skrif en Kerk, 13(1): 6579.

WATSON, W.G.E. 1980. (iender-matched Synonymous Parallelism in the OT. Joumal of Biblical Literature, 99 (3): 321-341. 
Psalm 122: Jerusalem reviviscut!

WATSON, W.G.E. 1986. Classical Hebrew Poctry: A Guide to Its Techniques, 2nd edition. Shefficld : JSOT Press. (Journal for the Study of the Old Testament Supplement Serics 26.)

WEISER, A. 1966. Die Psalmen, Götingen: Vandenhoeck \& Ruprecht. (Das Alte Testament Deutsch $14 / 15$.)

WEISS, M. [1961] 1976. Wege der neuen Dichtungswissenschaft in iher Anwendung auf die Psalmenforschung. (In Neumann, P.H.A., Hrsg. Zur neuren Psalmenforschung. Darmstadı : Wissenschaftliche Buchgesellschaft. p. 400-451.) (Wege der Forschung 192.) 